\title{
Mid- to Late-Holocene estuarine infilling processes studied by radiocarbon dates, high resolution seismic and biofacies at Vitoria Bay, Espirito Santo, Southeastern Brazil
}

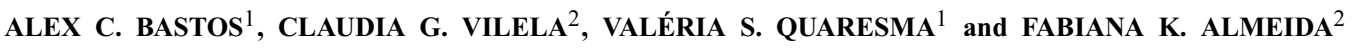 \\ ${ }^{1}$ Laboratório de Oceanografia Geológica, Departamento de Oceanografia e Ecologia \\ Universidade Federal do Espírito Santo, Av. Fernando Ferrari, 514 \\ Goiabeiras, 29090-000 Vitória, ES, Brasil \\ ${ }^{2}$ MicroCentro, Laboratório de Análise Micropaleontológica, Departamento de Geologia, Instituto de Geociências \\ Universidade Federal do Rio de Janeiro, Rua Athos da Silveira Ramos, 274 \\ Cidade Universitária, 21941-916 Rio de Janeiro, RJ, Brasil
}

Manuscript received on December 15, 2008; accepted for publication on April 14, 2010

\begin{abstract}
Vitoria Bay is a $20 \mathrm{~km}$ long estuary, morphologically narrow, with a microtidal regime and, as other modern estuaries, was formed during the last post-glacial transgression. The estuarine bed morphology is characterised by a main natural channel limited by tidal flats with developed mangroves. Original radiocarbon dates were obtained for the site. Five radiocarbon ages ranging from 1,010 to 7,240 years BP were obtained from two sedimentary cores, which represent a $5 \mathrm{~m}$ thick stratigraphic sequence. The results indicate that, until about 4,000 cal. yrs BP, environmental conditions in Vitoria Bay were still of an open bay, with a free and wide connection with marine waters. During the last 4,000 yrs, the bay has experienced a major regression phase, by becoming more restricted in terms of seawater circulation and probably increasing tidal energy. Three main stratigraphic surfaces were recognised, which limit trangressive, trangressive/highstand and regressive facies. The present channel morphology represents a tidal scouring surface or a tidal diastem, which erodes and truncates regressive facies bedding. Foraminiferal biofacies, which change from marine to brackish and mangrove tidal-flat environments, support the seismic stratigraphic interpretation. Absence of mangrove biofacies at one of the two cores is also an indication of modern tidal ravinement.
\end{abstract}

Key words: high-resolution seismic, Holocene estuarine evolution, radiocarbon dating, Vitoria Bay, biofacies.

\section{INTRODUCTION}

Modern estuaries in Brazil were developed during the last postglacial marine transgression, when downstream river valleys and coastal lowlands were flooded. In general, estuaries are considered as ephemeral geological features that are infilled by fluvial and marine sedimentary processes, which lead to the development of coastal sedimentary plains. Facies models and resultant estuarine infill sequences have been proposed elsewhere by several authors, either for transgressive and regressive

Correspondence to: Claudia Gutterres Vilela

E-mail: claudiagvilela@ufrj.br coasts (e.g. Allen and Posamentier 1993, Nichol et al. 1994, Lessa and Masselink 1995, Lessa et al. 1998, Lobo et al. 2003). General estuarine stratigraphic models are described by Dalrymple et al. (1992) based on the interaction between prevailing marine and fluvial processes. An estuarine infill sequence can be described, from base to top, by a lowstand, coarse sand or gravel fluvial facies followed by estuarine transgressive muds topped by a maximum flooding surface. Relative sealevel fall is characterised by regressive muddy and/or sandy facies. Variations of facies characteristics occur due to distinct relative sea-level trends, rates of sedi- 
ment supply, availability of accommodation space and prevailing hydrodynamic conditions (tides and waves). Time duration for a complete estuarine infill depends on relative sediment supply and creation rates of accommodation space. In Brazil, some estuaries have been studied in order to understand the sedimentary infill processes (e.g. Lessa et al. 1998, Souza Filho et al. 2006). However, there are still many unanswered questions in terms of their evolution along the eastern Brazilian regressive coast (Lessa 2005).

Herein, radiocarbon dates obtained from estuarine infilled deposits at Vitoria Bay (Fig. 1), Espirito Santo State, SE Brazil, are presented in association with highresolution seismic data and micropaleontological unpublished data from a MSc dissertation (F.K. Almeida, unpublished data). The main purpose of the present study is to present new radiocarbon dates obtained from an estuarine infilling sequence and their meaning in terms of changes in estuarine sedimentary processes during the Holocene. An attempt is made to fit dated and recognised seismic bounding surfaces within midto late-Holocene relative sea-level curves for the eastern Brazilian coast.

\section{RELATIVE SEA-LEVEL CURVES: EASTERN BRAZILIAN COAST}

Relative sea-level fluctuation curves for the eastern Brazilian coast have been investigated for more than 30 years, and the main results and discussions are presented, for example, by Delibrias and Laborel (1969), Suguio et al. (1985), Martin et al. (1993, 1998, 2003), Angulo and Lessa (1997), Lessa and Angulo (1998), Martin (2003) and Angulo et al. (2006).

Generally, all these studies are based on radiocarbon dates in different materials, which point out the occurrence of a mid-Holocene sea-level highstand at about 5,100 years BP, followed by a fall to the current mean sea-level. The main disagreement is related to the time when relative sea-level crossed above the current mean sea-level, time and elevation of the maximum transgression and the nature of late-Holocene sealevel fall (Angulo et al. 2006). Studies undertaken by Martin, Suguio and others (for example, Suguio et al. 1985, Martin et al. 1993, Martin 2003) have proposed that eastern Brazilian coast has undergone a submer- gence phase during the last 7,000 years, with a maximum highstand at about 5,100 years BP $(5,600$ cal years BP), reaching up to $5 \mathrm{~m}$ above the current mean sea-level (elevations can range locally from 2 to $5 \mathrm{~m}$ ). During the last 5,000 years, relative-sea level has dropped, but two periods of high-frequency oscillations occurred between 4,300-3,500 cal yr BP and 2,700-2,100 cal yr BP. These are calibrated calendar years for Salvador curve (Martin 2003), but these oscillations were observed, according to the authors, along others sectors of the eastern Brazilian coast.

A major discussion about time of sea-level highstand and nature of falling relative sea-level began with Angulo and Lessa (1997) and was followed by Martin et al. (1998), Lessa and Angulo (1998), Martin (2003) and Angulo et al. (2006). Reviewing relative sea-level curves for Parana and Cananeia regions, Angulo and Lessa (1997) concluded that there was no indication of the two high-frequency oscillations, and that rates of sea-level fall were lower than earlier suggested (Suguio et al. 1985, Martin et al. 1993). A critical review of all the radiocarbon dated samples to established relative sea-level curves to the eastern Brazilian coast was undertaken by Angulo et al. (2006). The authors found that about $70 \%$ of the dated samples were misinterpreted or rather inaccurate indicators of sea-level. Using only radiocarbon dates from what was considered as accurate sea-level indicators (about only $30 \%$ of all the available dates), the authors present a sea-level envelop trend for the last 7,000 years. The results show a rather smooth drop in sea-level after the maximum transgression, between 4,900 yrs BP $-5,100$ cal yrs BP and 5,400 yrs BP $-5,700$ cal yrs BP (Angulo et al. 2006), and no evidence of high-frequency oscillations. Milne et al. (2005) have applied a realistic model of glaciation-induced sea-level change to the Caribbean and South America. The authors have compared radiocarbon dates obtained for Pernambuco, Rio de Janeiro and Santa Catarina coastline with model predictions. Data from Rio de Janeiro and Santa Catarina showed a good agreement with model predictions. Mean sea-level crossing time was predicted to have taken place at around 8,000 cal years BP, with a maximum transgression reaching up to $4.5 \mathrm{~m}$ at around 7,200 cal years BP (for Rio de Janeiro).

Concerning Espirito Santo State, where this inves- 


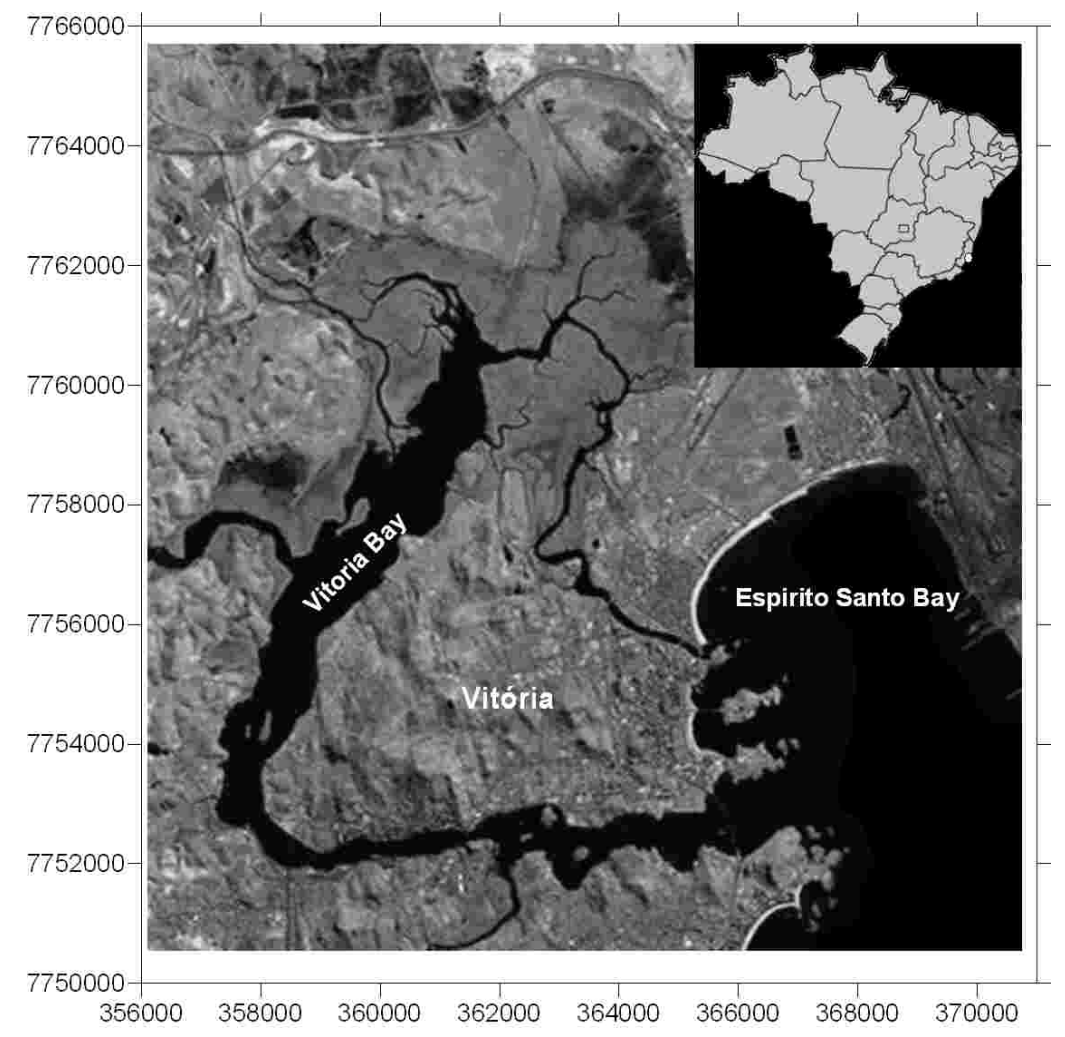

Fig. 1 - Location of the study area (Landsat image source: Embrapa).

tigation was carried out, no sea-level curve has been proposed so far. A few radiocarbon dates were obtained along the coast, especially at the Doce River coastal plain. Martin et al. $(1996,1997)$ have presented radiocarbon dates along the southern coast of Espirito Santo, closer to Vitoria Bay. Dates are presented as radiocarbon ages, with no calibration to calendar years. Plotting the available dates reveals a maximum transgression up to $3.5 \mathrm{~m}$ above mean sea-level, which occurred around 5,410 years BC (Fig. 2). This is fairly in agreement with sea-level curves proposed for eastern Brazilian coast (Martin et al. 1993, Angulo and Lessa 1997).

\section{STUDY AREA}

Vitoria Bay is located along the southeastern Brazilian coast and harbours one of the most important national ports, Porto de Vitoria (Fig. 1). It is about $20 \mathrm{~km}$ long and less than $0.5 \mathrm{~km}$ wide. The estuary has a microtidal regime, with-semi diurnal tides. Peak tidal currents can reach $0.5 \mathrm{~m} / \mathrm{s}$, and the estuary is ebb flow dominated (Rigo 2004). The main navigation channel is constantly dredged, and the lower reaches of the bay presents a significant anthropogenic influence. The upper reaches are bordered by tidal flats with relatively preserved mangrove forests and no dredging activities. Morphologically, the upper reaches are characterised by a narrow submerged tidal channel, up to $8 \mathrm{~m}$ deep with shallow margins, less than $0.5 \mathrm{~m}$ deep during low water. Sediment distribution is of predominantly sandy mud with widespread shell fragments. Fluvial sands are very restricted to Santa Maria da Vitoria river mouth and along narrower margins.

\section{METHODS}

In order to investigate the estuarine deposits, high-resolution seismic surveys were undertaken during 2006 and 2007. Seismic data were acquired using a Stratabox sub-bottom profiler, which operates at $10 \mathrm{kHz}$, and was processed and interpreted using SonarWizmap-SBP from Chesapeake Technology Inc. Based on the seismic results, a total of 12 cores were collected using diveroperated piston-push corer at the upper reaches of the 


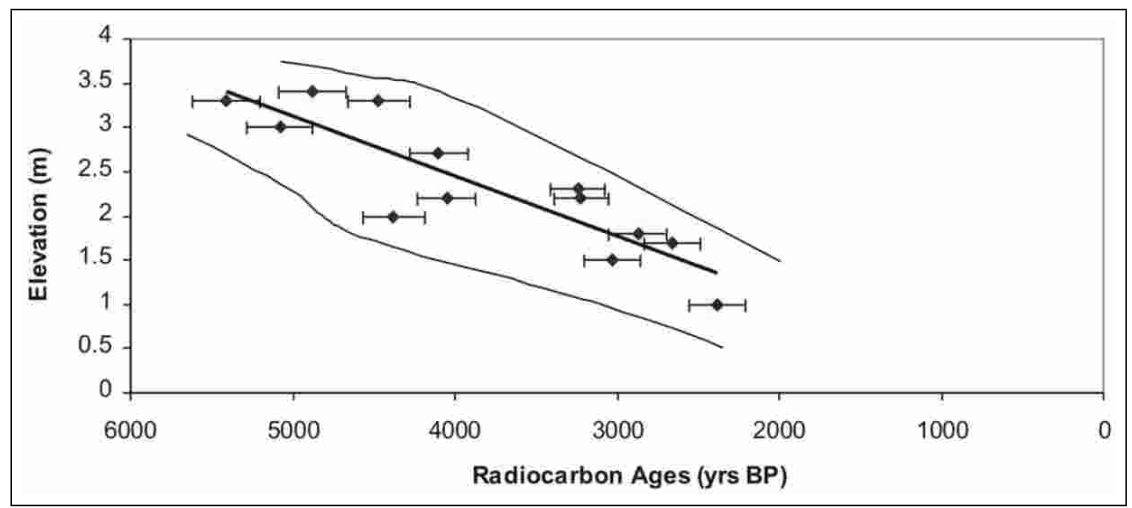

Fig. 2 - Radiocarbon dates obtained from Martin et al. $(1996,1997)$ for the coast between Serra (ES) and Guarapari (ES), south coast of Espirito Santo State.

bay. Herein, only two cores and one seismic section with cores locations are presented. It is important to emphasise that these cores were located where thicker stratigraphic record was available. Therefore, according to the seismic records, one core (1.66m long BV-T2) was obtained from the margin of the tidal channel, and the second one (2.30m long BV-T3) was collected from the bottom of the channel (Fig. 3).

These cores were opened, photographed, macroscopically described and sub-sampled for the following analysis: sediment grain size and mineral composition (M.M. Passos, unpublished data), benthic foraminifera (F.K. Almeida, unpublished data) and radiocarbon dating.

Shell samples and organic sediments from BV-T2 (50, 88 and $150 \mathrm{~cm}$ from the top) and BV-T3 (100 and $230 \mathrm{~cm}$ from the top) were collected and sent to Beta Analytics Radiocarbon Laboratory (Florida, USA). Radiocarbon measurements were taken with the AMS method, and dates are reported as radiocarbon years before present (present $=$ AD 1950). Calendar calibrated results are calculated from the Conventional Radiocarbon Age (Talma and Vogel 1993, INTCAL04 2004) using two sigma calibration (Variables used: $\mathrm{C} 13 / \mathrm{C} 12=-3.1 ; \Delta \mathrm{R}$ $=-8 \pm 69$; Glob. Res $=-200$ to 500 ).

\section{RESULTS}

A representative seismic section reveals the presence of a main tidal channel, about $7 \mathrm{~m}$ deep, with a thin veneer $(15 \mathrm{~cm}$ thick) of modern sedimentation, charac- terised by fluid muds (Fig. 4a). A basal reflector is observed at about $5 \mathrm{~m}$ below the bed, which represents the acoustic basement, and probably the bedrock (Fig. 4b). A first-order reflector is defined here as an unconformity and/or a seismic facies boundary. Three main seismic facies boundaries were observed (SB1, SB2, SB3). Second-order reflectors were recognised and describe the large-scale internal structure of the deposits.

SB1 is characterised by a strong, continuous and very irregular/erosive reflector, which marks the top of the lower seismic unit (Fig. 4b). This seismic unit is characterised by a reflection free signature with a few irregular second-order reflectors. Sediment samples from Core BV-T3, which was collected at the bottom of the channel, show an $80 \mathrm{~cm}$ thick greenish mud facies with sparse shell fragments at the base of the core $(>85 \%$ mud). The top of this greenish mud facies is marked by a sandy $/ \mathrm{shell}$ hash layer at $140 \mathrm{~cm}$ interval, which defines SB1 (Fig. 5). The base of the core was dated for 7,240 cal. yrs BP, and is represented by a continuous sub-parallel second-order reflector (Table I).

Above SB1, a seismic facies unit is characterised by inclined reflectors onlapping this bounding surface. BV-T3 shows that this unit consists of mud deposits intercalated with 5 to $10 \mathrm{~cm}$ thick fine sand layers. A fine sand layer at $100 \mathrm{~cm}$ was dated for 3,980 cal. yrs BP. This seismic unit is topped by SB2, which is a horizontal and continuous reflector that may be associated with a $10 \mathrm{~cm}$ thick shell hash layer observed at $50-40 \mathrm{~cm}$ in BV-T3. This core also presents a $15-20 \mathrm{~cm}$ thick fluid mud modern deposit at the top. 


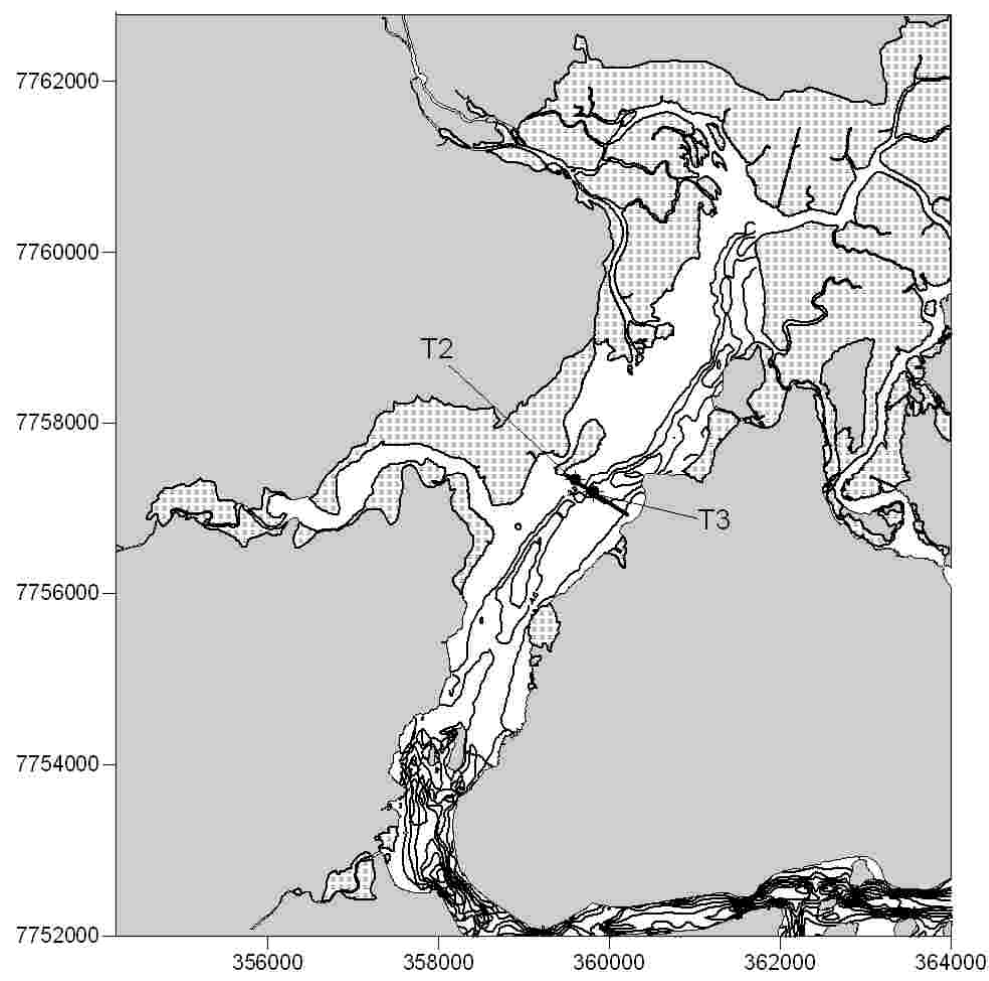

Fig. 3 - Core locations in relation to the present bottom morphology.
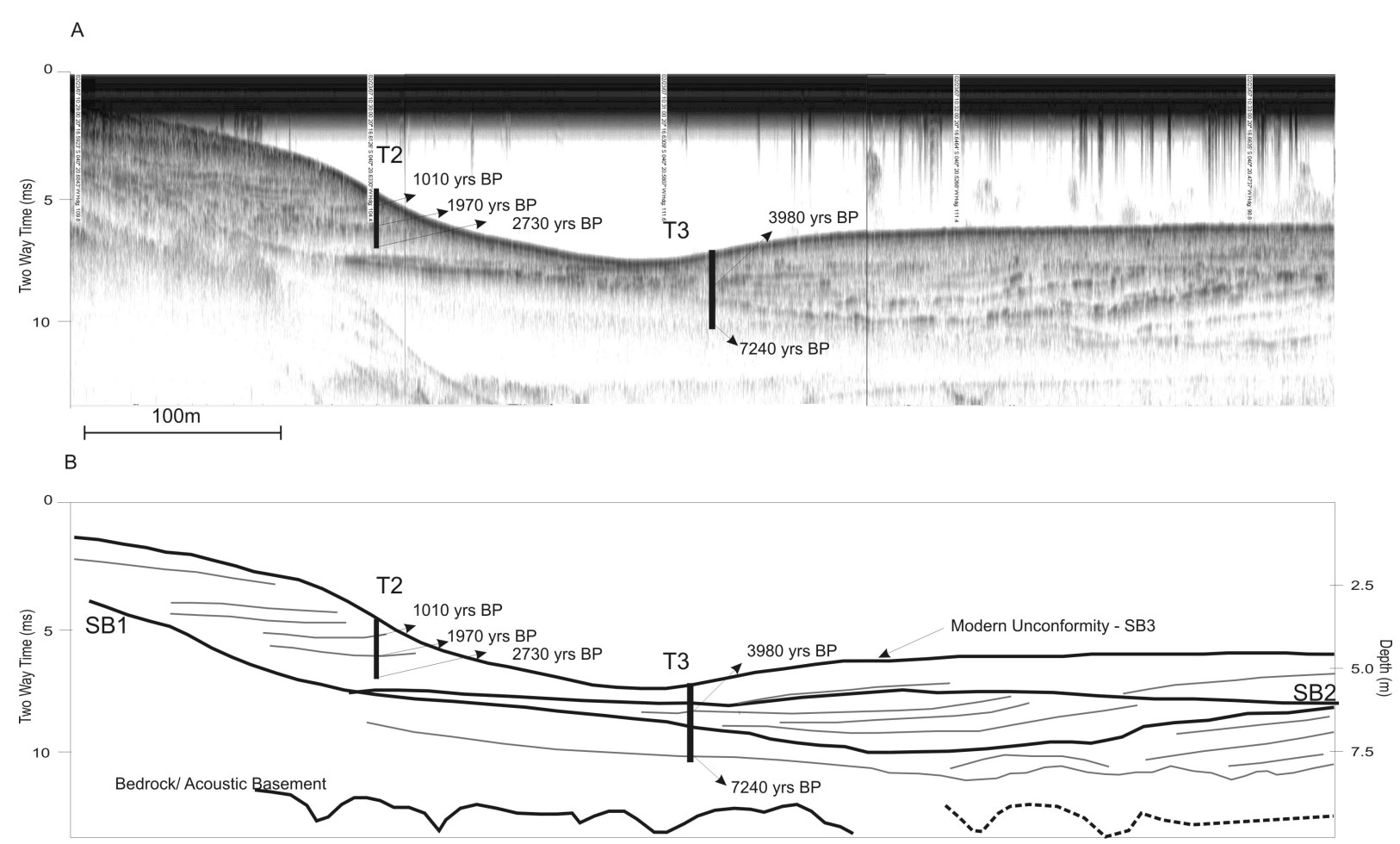

Fig. 4 - High-resolution seismic section (a) and interpretation (b). Core locations and radiocarbon dates are presented. See text for the meaning of SB1 and SB2. 
TABLE I

Radiocarbon dating results.

\begin{tabular}{c|c|c|c}
\hline Sample & $\begin{array}{c}\text { Conventional } \\
\text { radiocarbon age } \\
\text { (years BP) }\end{array}$ & $\begin{array}{c}\text { Calendar calibrated } \\
\text { result (2 Sigma) } \\
\text { (years BP) }\end{array}$ & $\begin{array}{c}\text { Interception of } \\
\text { radiocarbon age } \\
\text { at cal curve }\end{array}$ \\
\hline BV-T2-50 cm & $1,460 \pm 40$ & $1,210-880$ & 1,010 \\
BV-T2-88 cm & $2,340 \pm 40$ & $2,150-1,800$ & 1,970 \\
BV-T2-150 cm & $2,950 \pm 40$ & $2,890-2,540$ & 2,730 \\
BV-T3-100 cm & $3,660 \pm 40$ & $4,120-3,830$ & 3,980 \\
BV-T3-230 cm & $6,280 \pm 50$ & $7,380-6,890$ & 7,240 \\
\hline
\end{tabular}

The upper most seismic unit is characterised by parallel to sub-parallel reflectors that are truncated by an irregular reflector representing the major modern unconformity - SB3 (channel topography associated with modern sedimentation). These seismic reflectors are represented by BV-T2 core sediments (e.g. Fig. 5). The core is characterised by an intercalation of sandy mud and muddy sand layers with a $10 \mathrm{~cm}$ thick main shell hash layer at $50 \mathrm{~cm}$, which gives a calendar age of $1,010 \mathrm{cal}$ yrs BP. This intercalation is observed down to $70 \mathrm{~cm}$, where the core becomes dominantly muddy with shell fragments well distributed down to the base of the core. Two more time horizons were obtained along this core: $1,970 \mathrm{cal}$. yrs BP at $88 \mathrm{~cm}$ and $2,730 \mathrm{cal}$. yrs BP at $150 \mathrm{~cm}$ (e.g. Fig. 4, Table I).

F.K. Almeida (unpublished data) has carried out a paleoenvironmental analysis based on benthic foraminifera assemblage sampled from BV-T2 and BV-T3. Results are graphically presented in Figure 5. Based in statistical analyses including similarity and cluster analyses, the author has recognised four biofacies: NP (dominant species: Nonion depressulus and Pseudononion atlanticum), $\mathrm{CG}$ (Cribroelphidium gunteri, C. vadescens and Globocassidulina subglobosa), AE (Ammonia parkinsoniana, A. tepida and Elphidium spp.) and AT (Ammotium morenoi and textularids). NP and CG were only observed along BV-T3, from 150 to $230 \mathrm{~cm}$ and from 90 to $150 \mathrm{~cm}$, respectively. These biofacies are typical of inner shelf open sea environment. A transition zone from $\mathrm{CG}$ to $\mathrm{AE}$ biofacies were recognised between $60 \mathrm{~cm}$ to $90 \mathrm{~cm}$ in BV-T3. Biofacies AE was predominant at BVT3 from 10 to $60 \mathrm{~cm}$, and at BV-T2 it was observed from 40 to $160 \mathrm{~cm}$. This biofacies refers to a brackish environment. Biofacies AT is typical of agglutinated tests and was observed at the top of BV-T2, which represents mangrove-tidal flat environments.

\section{DISCUSSION}

An integrated analysis of high-resolution seismic data, core sediment texture and foraminiferal biofacies with radiocarbon dates allowed a preliminary interpretation of the late-Holocene infilling processes in Vitoria Bay estuary. Considering a stratigraphic sequence framework, the available dataset did not present any record or evidence of lowstand fluvial deposits. The interpreted acoustic basement represents the bedrock and there is no seismic evidence, within the section shown herein, of fluvial deposits resting on top of the bedrock. Moreover, the cores did not reach the bedrock basement, so there is no record of the entire sedimentary sequence above the bedrock.

The first observed bounding surface, SB1, is being interpreted as a tidal ravinement surface (TRS). SB1 is defined by a higher sand content layer $(\sim 45 \%)$ and shows a change in biofacies, from NP to CG. This surface is quite irregular, which indicates a possible erosive process, probably due to an increase in the tidal action. The seismic unit below SB1 is interpreted as transgressive mud facies representing an open sea environment, as defined by benthic foraminifera analysis (NP biofacies). The base of this trangressive facies was dated for $7,200 \mathrm{yrs} \mathrm{BP}$, which is around the time of relative sealevel crossing the current sea-level. The seismic unit resting above SB1 is characterised by reflectors onlapping this TRS, which may represent a continuous transgressive or a highstand phase. This unit consists of mud/sand facies, which still represents an open sea environment based on the benthic foraminifera analysis 
A) BV-T2

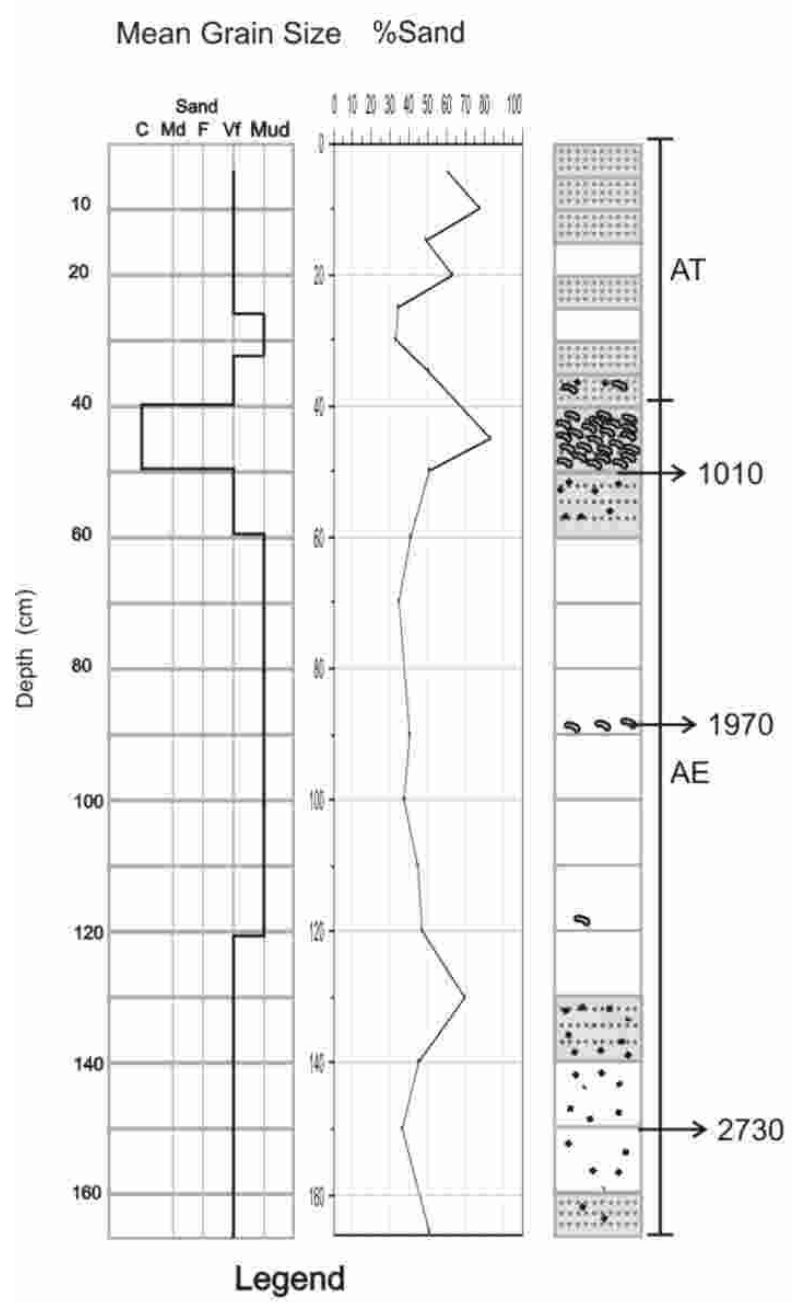

B) BV-T3

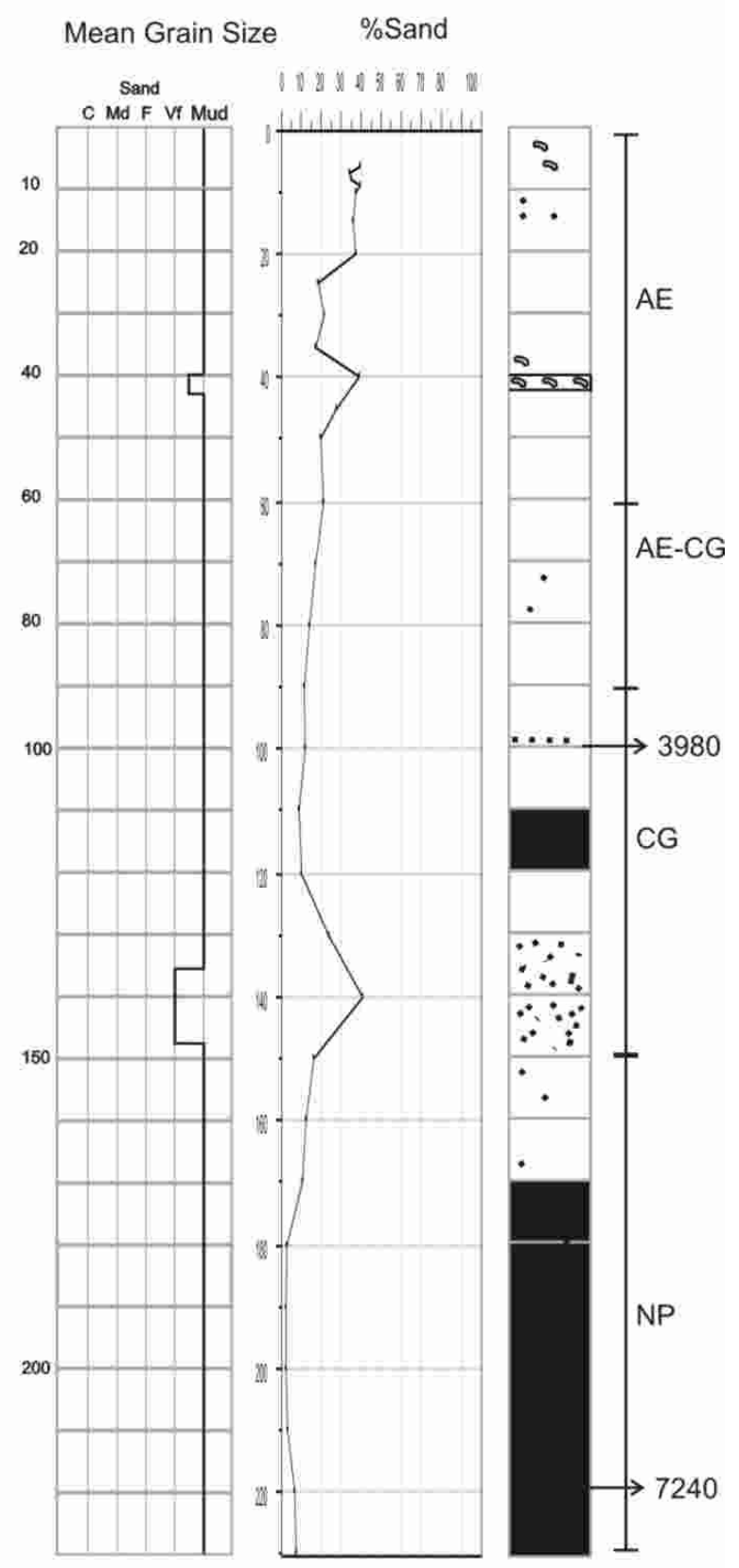

AT, AE, CG, NP

Muddy Sand

Mud

Sandy Mud

Shell Tests

Shell Fragments

$\longrightarrow 1970$ Radiocarbon dates - cal yrs BP

Fig. 5 - Schematic interpretation of BV-T2 (A) and BV-T3 (B), including sediment texture, sand content, biofacies distribution and radiocarbon dates. See text for biofacies description. 
(CG biofacies). The top of this unit was dated for 3,980 cal. yrs BP, which would fit in the regressive phase, in a general relative sea-level curve for the eastern Brazilian coast. However, considering all the discussion regarding the time and duration of the Holocene highstand, it is possible that highstand conditions have lasted until around 4,000 yrs BP, or sediment input was too low to start a regressive phase. By analysing the sea-level envelop proposed by Angulo et al. (2006), it is clear that sea-level has dropped very gently after the highstand. Assuming this interpretation, this unit represents a transgressive-highstand facies.

Bounding surface SB2 represents a basal regressive surface (RS), which separates transgressive/highstand and regressive estuarine facies. The regressive seismic unit shows reflectors downlapping RS along the western end of the section and parallel to sub-parallel reflectors along the eastern end, which are truncated by SB3 (modern unconformity). The regressive mud/sand facies is associated with a clear increase in sand content, which was observed at 70 to $60 \mathrm{~cm}$ of BV-T3 and continuously along BV-T2 ( 40-50\%). A significant change in benthic foraminifera assemblage was observed along BV-T3. Biofacies AE dominates in the top $60 \mathrm{~cm}$ of $\mathrm{BV}-\mathrm{T3}$, and is associated with a brackish environment, which documents a decrease in salinity and in open sea circulation. Biofacies $\mathrm{AE}$ is dominant along BV-T2 from 166 to $40 \mathrm{~cm}$, which dates for around $1000 \mathrm{yrs}$ BP. The top of this regressive facies is characterised by a change in benthic foraminifera assemblage (AT biofacies). Agglutinated foraminifera become dominant, which indicate the establishment of mangroves.

The modern channel morphology is described as a major unconformity (SB3) that truncates regressive estuarine beddings, at least 1,000 cal yrs old. It may represent a regressive ravinement surface due to tidal scouring along the main channel, or a tidal diastem, as defined by Lessa et al. (1998) for Paranagua Bay. Considering a gentle drop in relative sea-level during the last 4,000 yrs (Angulo et al. 2006), it is also possible that this surface has changed its position due to tidal channel meander.

Hitherto, the results obtained for this estuarine system indicate that, until around 4,000 cal. yrs BP, environmental conditions were still of an open bay, with a free and wide connection with marine waters. This may rep- resent highstand conditions with low rates of sediment supply. Evidences of a regressive phase are supported by reflectors downlapping onto a regressive surface and the establishment of typical brackish water and mangrove foraminifera assemblages.

\section{CONCLUSIONS}

Original radiocarbon ages ranging from 1,010 cal. yrs $\mathrm{BP}$ to 7,240 cal. yrs BP were obtained from two sedimentary cores in Vitoria Bay, representing a 5m thick stratigraphic sequence. Seismic interpretation has allowed the recognition of different seismic facies and estratigraphic surfaces.

The results indicate that, until around 4,000 cal. yrs BP, environmental conditions in Vitoria Bay were still of an open bay, with a free and wide connection with marine waters. These phases are characterised by trangressive mud facies separated from trangressive/highstand mudsand facies by a tidal ravinement surface. Regressive facies rest on the top of a regressive surface younger than 4,000 yrs BP, and are characterised by an increase in sand content and the establishment of typical brackish water and mangrove foraminifera assemblages. Radiocarbon dates within the regressive facies show ages ranging from 2,700 to $1,010 \mathrm{cal}$. yrs BP. The present channel morphology represents a tidal scouring surface or a tidal diastem, which erodes and truncates regressive facies bedding and, locally, may also expose trangressive facies.

It is important to note that the results and conclusions here presented correspond to a first interpretation of mid- to late-Holocene processes in Vitoria Bay. A complete analysis of seismic data acquired for the entire bay, together with more core analysis, will provide a better understanding of the infilling processes during the Holocene.

\section{ACKNOWLEDGMENTS}

Funding for this study was provided by Fundação de Amparo à Pesquisa do Espírito Santo (FAPES). Radiocarbon dating was funded by Agência Nacional do Petróleo - PRH-29/UFES and Conselho Nacional de Desenvolvimento Científico e Tecnológico (CNPq) productivity Grant. The authors are grateful to Laboratório de 
Geologia Marinha, Universidade Federal Fluminense, for providing the sub-bottom profiler. Special thanks are also to the revisers of the manuscript.

\section{RESUMO}

A Baía de Vitória é um estuário com $20 \mathrm{~km}$ de comprimento, morfologicamente estreito, com um regime de micromaré e, como outros estuários modernos, formado durante a última transgressão pós-glacial. A morfologia de fundo do estrato estuarino é caracterizada por um canal natural principal limitado por planícies de maré com manguezais desenvolvidos. Datações de radiocarbono originais foram obtidas para a área. Cinco idades de radiocarbono estendendo-se de 1.010 a 7.240 anos AP foram obtidas através de dois testemunhos de sedimento, representando uma sequência estratigráfica de $5 \mathrm{~m}$ de espessura. Os resultados indicam que até aproximadamente 4.000 anos cal. AP, as condições ambientais da Baía de Vitória eram ainda de uma baía aberta, com uma conexão livre e aberta com águas marinhas. Durante os últimos 4.000 anos a baía experimentou uma fase de regressão importante, tornando-se mais restrita em termos de circulação da água do mar e provavelmente aumentando a energia de marés. Três superfícies estratigráficas principais foram reconhecidas, limitando fácies transgressiva, transgressiva/nível de mar alto e regressiva. A morfologia do canal atual representa um diastema de maré, mostrando fácies regressivas truncadas e erodidas. Biofácies de foraminíferos, passando de ambiente marinho para ambiente salobro e de manguezais em planície de maré confirmam a interpretação sismoestratigráfica. A ausência de biofácies de mangue em um dos dois testemunhos é também uma indicação de ravinamento de maré atual.

Palavras-chave: sísmica de alta-resolução, evolução estuarina holocênica, datação por radiocarbono, Baía de Vitória, biofácies.

\section{REFERENCES}

Allen GP And Posamentier HW. 1993. Sequence stratigraphy and facies model of anincised valley fill: the Gironde estuary, France. J Sediment Petrol 63: 378-392.

Angulo RJ And Lessa G. 1997. The Brazilian sea level curves: a critical review with emphasis on the curves from Paranagua and Cananeia regions. Mar Geol 140: 141166.

Angulo RJ, Lessa GC And Souza MC. 2006. A critical review of mid- to late-Holocene sea-level fluctuations on the eastern Brazilian coastline. Quatern Sci Revs 25: 486-506.

DALRYMPle RW, ZATtLin BA AND Boyd R. 1992. Estuarine facies models: conceptual basis and stratigraphic implications. J Sediment Petrol 62: 1130-1146.

DELIBRIAS C AND LABOREL J. 1969. Recent variations of the sea level along the Brazilian coast. Quaternaria 14: 45-49.

INTCAL04. 2004. Radiocarbon age calibration. Calibration Issue of Radiocarbon 46(3).

LESSA GC. 2005. Baías Brasileiras: grandes estuários em uma costa regressiva? Simp Baías, $10^{\circ}$ Cong. ABEQUA, Guarapari-ES, Anais, CD-ROM.

LESSA GC AND ANGULO RJ. 1998. Oscillations or not oscillations, that is the question-reply. Mar Geol 150: 189-196.

Lessa GC AND MASSElinK G. 1995. Sedimentation and hydrodynamic changes in a backbarrier macrotidal estuary: a morphodynamic approach. Mar Geol 129: 25-46.

Lessa GC, Meyers S And Marone E. 1998. Holocene stratigraphy in the Paranagua Bay estuary, south Brazil. J Sediment Res 68(6): 1060-1076.

Lobo FJ, Dias JMA, Gonzalez R, Hernandez-MoliNA FJ, Morales JA AND Diaz Del Rio V. 2003. High Resolution Seismic Stratigraphy of a narrow, bedrockcontrolled estuary: The Guadiana Estuarine System, SW Ibéria. J Sediment Res 73: 973-986.

Martin L. 2003. Holocene Sea-Level History Along Eastern-Southeastern Brazil. Anuário IGEO, UFRJ, 26 WorkshopBaía: 13-24.

MARtin L, Suguio K ANd FleXor J-M. 1993. As flutuações do nível do mar durante o Quaternário superior e a evolução geológica de "deltas" brasileiros. Bol IG/USP 15: 186.

Martin L, Suguio K, Flexor JM, Dominguez JML AND BITTENCOURT ACSP. 1996. Quaternary sea-level history and variation in dynamics along the central Brazil Coast: consequences on coastal plain construction. An Acad Bras Cienc 68: 303-354.

Martin L, Suguio K, Dominguez JML and Flexor JM. 1997. Geologia do Quaternário costeiro do litoral norte do Rio de Janeiro e do Espírito Santo. CPRM Serv Geol Brasil, 112 p.

Martin L, Bittencourt ACSP, Dominguez JML, FLEXOR JM AND SUguio K. 1998. Oscillations or not oscillations, that is the question: comment on Angulo R.J. and Lessa G.C. "The Brazilian sea-level curves: a critical review emphasis on the curves from the Paranagua and 
Cananeia regions" [Mar Geol 140: 141-166]. Mar Geol 150: $179-187$.

Martin L, Dominguez JML And Bittencourt ACSP. 2003. Fluctuating Holocene sea levels is eastern and southeastern Brazil: evidence from a multiple fossil and geometric indicators. J Coast Res 19: 101-124.

Milne GA, Long AJ And Bassett E. 2005. Modeling Holocene relativesea-level observations from the Caribbean and South America. Quatern Sci Revs 24: 11831202.

Nichol SL, Boyd R AND PEnLAND S. 1994. Stratigraphic response of wave dominated estuaries to different relative sea-level and sediment supply histories: Quaternary case studies from Nova Scotia, Louisiana and eastern Australia. In: DALRYMPLE R AND BOYD R (Eds), Incised-Valley Systems: Origin and Sedimentary Sequences, SEPM Sp Publ 51: 265-283.
RIGO D. 2004. Análise do escoamento em regiões estuarinas com manguezais - medições e modelagem na Baía de Vitória, ES. Tese de Doutorado, Programa de PósGraduação em Engenharia Oceânica, COPPE, UFRJ, $200 \mathrm{p}$.

Souza Filho W M, COHEN MCL, LARA RJ, Lessa GC, Koch B AND BeHLing H. 2006. Holocene coastal evolution and facies model of the Bragança macrotidal flat on the Amazon Mangrove Coast, Northern Brazil. J Coast Res, Sp Issue 39: 306-310.

Suguio K, Martin L, BitTencourt ACSP, Dominguez JML, Flexor JM AND AzEvedo AEG. 1985. Flutuações do nível relativo do mar durante o Quaternário Superior ao longo do litoral brasileiro e suas implicações na sedimentação costeira. Rev Bras Geoc 15: 273-286.

Talma AS And Vogel JC. 1993. A Simplified Approach to Calibrating C14 Dates. Radiocarbon 35(2): 317-322. 